\title{
Demonstration and Performance Evaluation of Dual Purpose "Potchefstroom koekoek" Chickens Under Farmers' Management Conditions in the High Land Areas of Arsi zone, Oromiya Region
}

\author{
Mulualem Ambaw* Mezgeb Werkiye \\ Ethiopian Institute of Agricultural Research, Kulumsa Agricultural Research Center \\ P.O.Box 489, Assela ,Ethiopia
}

\begin{abstract}
The study was conducted to demonstrate and evaluate performance of dual purpose Potchefstroom koekoek chicken with full package under farmers' management system in the highland areas of Arsi zone, Oromia Region.A total of 18 farmers were selected purposively based on previous experience in poultry rearing, willingness to construct or modify poultry house, access to market and research input availability. Training was given on all chicken management aspects. A total of 55 day-old chickens with other packages were delivered to each participant farmer in Tiyo and Sagure. Data was collected starting from day one following chicken delivery up to start of the first egg lay and continued until 72 week of age. The current study revealed that on average $9.4 \%$ and $5.8 \%$ of mortality was recorded per participant farmer up to eight weeks of age at Sagure and Tiyo District respectively. 202.3 days $(6.7 \mathrm{month})$ and $1.46 \mathrm{~kg}$ body weight was recorded on average for first egg lay. The daily percentage of hen- housed egg production per participant farmers was $41.7 \%$ at $50 \%$ ( 32 week) and $69.7 \%$ at 52 weeks of age with average egg weight of $49.8 \mathrm{~g}$ and $51.7 \mathrm{~g}$ respectively. Per participant farmer, on average 1244 birr was expended for purchase inputs and 5500.33 birr was gained from sale of egg, cockerels and replacement chickens as net income. The farmers became aware of the importance of the breed that adapted well under the existing farmers' management condition and performed better than indigenous breeds for egg and meat production.
\end{abstract}

Keywords: koekoek chickens, demonstration, on farm evaluation, mortality

DOI: $10.7176 / \mathrm{JESD} / 12-1-04$

Publication date: January $31^{\text {st }} 2021$

\section{Introduction}

In most part of Ethiopia, village chicken represents a significant component of the rural household livelihood as a source of cash income for immediate household expenses and nutrition. Production of both egg and chicken meat has certainly assisted in reducing the gap in the supplies of animal protein for human consumption (Taddele and Ogle, 2001; Dhuguma, 2009; Leta and Bekana, 2010). In Ethiopia, indigenous poultry breeds produce eggs that are used for income generation and consumption, but their eggs production potential are invariably small as compared with those of exotic breeds. According to the MoA (1997) the annual egg production potential of Ethiopian hen ranges from 40-60 with a single egg weighing between 39 and 46g. Because of low performance of indigenous chicken breed of Ethiopia, different exotic chicken breeds (White Leghorn, Brown Leghorn, New Hampshire, Light Sussex, Barred Rock, Rhode Island Red, Fayoumi, etc have been introduced to Ethiopia (Alemu and Tadelle, 1998 ;Tadelle et al. 2003 ; Demeke, 2004 ; Wilson, 2010). However, lack of recorded data on the productive performance of chicken makes it difficult to assess the importance and contributions of the past attempts to improve the sector (Moges et al., 2010a).

Over the last decades, Bureau of agricultural extension of Arsi zone has been exercising to disseminate dominantly white leghorn and RIR as a poultry extension package to improve both production and Productivity of local chickens. But, experience indicated that the poultry extension Packages introduced by the government are not properly evaluated. Lack of recorded data on the Performance of chickens and in all aspect of managements makes difficult to assess the importance and contributions of the past attempt to the sector associated with the extension intervention efforts made so far.

On the other hand in the past few years Potchefstroom koekoek, a breed from crosses between the Black Australorp and the White Leghorn and recognized as a locally South African developed breed was distributed to some areas Ethiopia for the purpose of demonstration and production performance evaluation. The production potential of the breed is promising to scal up the technology to different areas. On the other hand production performance of the breed under farmers' management conditions in high land areas of Arsi zone was not evaluated for its further extension intervention. Kulumsa Agricultural Research Center is located in Arsi which is mandated to do research at the highland areas of Arsi Zone. The demand producer farmers about improved chicken breeds in our research mandate areas. This research was initiated to demonstrate and production performance evaluation of Koekoek chicken in highland agro ecology at the farmers management condition. 


\section{Materials and Methods}

\subsection{Description of the study area}

Tiyo and Digelu-Tijo districts are located at 175 and $200 \mathrm{~km}$ far from Addis Ababa in south-eastern Ethiopian respectively. Relatively the study sites are characterized by high rain fall, low temperature and cold weather condition throughout the year and the districts receives an average rain fall $600-900 \mathrm{~mm}$ per year. The annual minimum and maximum temperature is $11^{\mathrm{oc}}$ and $23^{\mathrm{oc}}$ respectively. The areas are predominantly described by mixed livestock-crop production system. Wheat, barley, pulse crops, vegetables and livestock production particularly dairy are the main agricultural practices in the study areas unpublished document (WOA, 2009).

\subsection{Participant farmer selection}

Participants were selected from the two districts with the help of agricultural experts working on poultry section based on the willingness to carry out the demonstration, previous experience to poultry practice, access to inputs house construction, feed preparation data collection and availability of market. A total of six female and twelve male producer farmers were participated at this demonstration and evaluation trial from both districts. Training on management of chicken; feeding watering, housing and disease prevention and control were given to the participant producer farmers, agricultural and veterinary experts before distributing the chicken. In addition, the types of chicken house construction and preparation of brooding materials were also given. Visiting and checking of the chicken house and brooding material construction were conducted before distributing the experimental chicken to producers

\subsection{Management of experimental birds}

A day old 990 koekoek chicks were purchased from Debrezeit Agricultural Research Center and distributed to eighteen (18) participant producers without consideration of male to female ratio. Equal numbers (55) chickens per participant farmer were distributed with full packages like feed, health for two months. The experimental chickens were vaccinated from day old up to 52 weeks of age against the most common chicken diseases to minimize mortality and risk of poultry disease outbreak. Then, after two months of age all participants allowed their chicken to scavenge around the home stead with supplementation of maize, wheat, wheat bran and house left over feed. Supplementation of Water was ad libitum during scavenging and when they were in shelter.

\subsection{Chicken brooding materials}

Participant farmers were used different brooding materials base on their capability and gain access to heat resources alternatives from day old up to two weeks of age. As shown in (Table1) Electric, Solomon hay-box and hot-pot was used for heat source separately and in combination depending on the daily temperature variability.

\subsection{Data collection}

Data collection was conducted by frequent travel and the producers themselves. Amount of feed given, feed left over, cost of feed , any health related problems, mortality, signs and symptoms of disease, medication ,weight gain , date at first maturity, date of the first egg laying, daily egg production, egg weight, income from sale of live chicken and egg were collected by participant farmers and researchers using data collecting format.

\subsection{Data analysis}

The collected data were analyzed using statistical package for social science version 20.descriptive statistics such as mean; frequency and percentage were used.

\section{Results and discussion}

\subsection{Mortality}

As shown in the summary table2, out of total delivered chicks (55) to each participant farmer, on average $10.9 \%$ and $8.6 \%$ mortality was observed at Sagure and Tiyo District respectively. The mortality difference among participant farmers and study sites was came up with differences in management practices and brooding materials used to grow chicks for the brooding period. Relatively high mortality was observed during brooding period at Sagure District because of very low temperature during distribution of chicks and employing of locally made chick brooding materials that was inefficient in protection of the transpired very low temperature. About $89 \%$ and $91.4 \%$ chickens were survived per farmer at Sagure and Tiyo District respectively. The mortality rate observed in this study was lower as compared to study of koekoek demonstration packages at Jima zone in Oromiya region, Areka area in SNNPR and Fayoumi chicks in Arsi - Negele district where 35.9\%, 20.2\% and 76.82\% mortality was reported by Kasa \&Saba (2016), Aman et al (2016) and Samson et al (2013) respectively. However the result obtained in this study was in agreement with Demeke (2004) who reported $5 \& 7 \%$ mortality for local and white leg horn chicks under scavenging and intensive system respectively. Mortality recorded after brooding period was negligible at both Districts per participants' poultry house. It could be attributed to the fact that proper deployment 
of vaccination against most disease incidence and conscious management practice of the participant farmers.

Table 2.mortality of chicken in the study districts up to the start of egg lying

\begin{tabular}{|c|c|c|c|c|c|}
\hline Districts & Participants & $\begin{array}{l}\text { No of chicken } \\
\text { given }\end{array}$ & The first 8 weeks & $\begin{array}{l}\text { Next } 8 \text { weeks } \\
\text { till the start of } \\
\text { egg laying }\end{array}$ & Survival \\
\hline \multirow[t]{9}{*}{ Digelu-Tijo } & 1 & 55 & 27 & 0 & 28 \\
\hline & 2 & 55 & 2 & 0 & 53 \\
\hline & 3 & 55 & 3 & 1 & 51 \\
\hline & 4 & 55 & 4 & 2 & 49 \\
\hline & 5 & 55 & 0 & 0 & 55 \\
\hline & 6 & 55 & 2 & 1 & 52 \\
\hline & 7 & 55 & 3 & 0 & 52 \\
\hline & 8 & 55 & 5 & 2 & 53 \\
\hline & 9 & 55 & 2 & 0 & 53 \\
\hline Total & & 495 & $9.7 \%$ & 1.2 & $89.1 \%$ \\
\hline \multirow[t]{9}{*}{ Tiyo } & 1 & 55 & 3 & 1 & 51 \\
\hline & 2 & 55 & 1 & 0 & 54 \\
\hline & 3 & 55 & 0 & 2 & 53 \\
\hline & 4 & 55 & 0 & 1 & 54 \\
\hline & 5 & 55 & 2 & 0 & 53 \\
\hline & 6 & 55 & 4 & 1 & 50 \\
\hline & 7 & 55 & 1 & 0 & 54 \\
\hline & 8 & 55 & 5 & 3 & 47 \\
\hline & 9 & 55 & 18 & 1 & 36 \\
\hline Total & & 495 & $6.8 \%$ & $1.8 \%$ & 91.4 \\
\hline
\end{tabular}

\subsection{The common cause of mortality}

The majority $45 / 97=46.4 \%$ of the chicken were lost at the first 4 weeks due to predator attack and the remaining $52 / 9754.6 \%$ were died because of diseases, stress and mechanical damage and sudden death with unknown causes. Diseases symptoms commonly encountered in the study chicken were whitish and bloody diarrhea and blindness, which were caused by fowl typhoid, coccidian and infectious coriza. Only $2 / 97=2.1 \%$ of the chicken were died because of mechanical damage at age of one week. $8 / 97=8.2 \%$ of them were died because of transport stress within 24 hours. The remaining 42/990=43.3\% mortality were caused by diseases mentioned above and suddenly with unknown cause.

\subsection{Measures taken during disease occurrence}

Isolation, treatment and burring were practiced for the control and prevention of the diseases. Based on the producers report and during continuous follow up, any chicken with disease signs and symptoms were isolated and treated with appropriate drugs .Sulphadrug for fowl typhoid, amprolium for cocidiosis and long acting Oxy Ttc as broad spectrum antibiotics were used for the treatment of any bacterial infections.

\subsection{Age and weight gain at sexual maturity}

The average age at sexual maturity under farmer's management condition was 202.7 days (6.8 month) and 198 days /6.6 months. Regarding average body weight gain at the first egg lying were 1.4 and $1.3 \mathrm{~kg}$ in Tiyo and Digelu-Tijo districts respectively. In this study, a longer age at sexual maturity was recorded as compared to the report of Aman et al (2016) and Grobbelaar et al(2010), who reported that age at sexual maturity of koekoek chickens was 142 and 138.5 days respectively. Desalew et al (2013) was also reported that the age at sexual maturity of koekoek chickens was 153 days at village management condition in Lume district, east shoa, Ethiopia. Our study result is similar with the report of Kasa \& Saba (2016) who described 219 days of sexual maturity was observed at Jima Zone. The delayed sexual maturity obtained during this study could be attributed to various factors such as poor management low feed supplementation and poor house management practices. The age at first egg laying and weight gain are listed under (table 3). 
Table 3.Age and weight gain at first egg laying in the study districts

\begin{tabular}{|c|c|c|c|c|c|}
\hline Districts & Participants & $\begin{array}{l}\text { No of chicken } \\
\text { given }\end{array}$ & $\begin{array}{lr}\text { Numbers } & \text { of } \\
\text { female chicken } \\
\text { reached for egg } \\
\text { laying }\end{array}$ & $\begin{array}{l}\text { age at first egg } \\
\text { laying }\end{array}$ & $\begin{array}{l}\text { Weight gain at } \\
\text { egg laying in } \mathrm{kg}\end{array}$ \\
\hline \multirow[t]{9}{*}{ Digelu-Tijo } & 1 & 55 & 22 & 180 & 1.2 \\
\hline & 2 & 55 & 34 & 210 & 1.4 \\
\hline & 3 & 55 & 32 & 200 & 1.1 \\
\hline & 4 & 55 & 29 & 185 & 1.5 \\
\hline & 5 & 55 & 38 & 210 & 1.1 \\
\hline & 6 & 55 & 35 & 210 & 1.2 \\
\hline & 7 & 55 & 31 & 210 & 1.2 \\
\hline & 8 & 55 & 33 & 210 & 1.5 \\
\hline & 9 & 55 & 30 & 210 & 1.3 \\
\hline Total & & 495 & 284 & 6.8 Month & 1.3 \\
\hline \multirow[t]{9}{*}{ Tiyo } & 1 & 55 & 34 & 210 & 1.5 \\
\hline & 2 & 55 & 33 & 200 & 1.2 \\
\hline & 3 & 55 & 38 & 230 & 1.1 \\
\hline & 4 & 55 & 37 & 220 & 1.3 \\
\hline & 5 & 55 & 30 & 180 & 1.5 \\
\hline & 6 & 55 & 31 & 200 & 1.4 \\
\hline & 7 & 55 & 32 & 210 & 1.4 \\
\hline & 8 & 55 & 29 & 182 & 1.6 \\
\hline & 9 & 55 & 24 & 150 & 1.7 \\
\hline Total & & 495 & 288 & 6.6 Month & 1.4 \\
\hline
\end{tabular}

\subsection{Body weight gain}

The body weight and body weight gain were recorded starting at day old, at the start of egg laying and mid and last time at 20,36 and 72 weeks of age respectively.

Table 4.weight gain of the chicken at different growth stage

\begin{tabular}{|c|c|c|c|c|}
\hline Districts & $\begin{array}{l}\text { Growth stages in } \\
\text { weeks }\end{array}$ & $\begin{array}{l}\text { Sample weighed } \\
\text { in gm }\end{array}$ & $\begin{array}{l}\text { Average Body weight } \\
\text { gram }\end{array}$ & $\begin{array}{l}\text { Average daily weight gain } \\
\text { in gram }\end{array}$ \\
\hline \multirow[t]{10}{*}{ Tiyo } & At day old & 450 & 32 & - \\
\hline & At 20 weeks old & & & \\
\hline & Female & 36 & 1.39 & 9.9 \\
\hline & Male & 18 & 1.6 & 11.4 \\
\hline & At 36 weeks old & & & \\
\hline & female & 27 & 1.44 & 5.1 \\
\hline & Male & 9 & 2.3 & 8.2 \\
\hline & At 72 weeks old & & & \\
\hline & Female & 18 & 1.53 & 3 \\
\hline & Male & 9 & 2.9 & 5.8 \\
\hline \multirow{11}{*}{$\begin{array}{l}\text { Digelu- } \\
\text { Tijo }\end{array}$} & & & & \\
\hline & Day old & 450 & 31 & \\
\hline & At 20 weeks old & & & \\
\hline & Female & 36 & 1.29 & 9.2 \\
\hline & Male & 18 & 1.4 & 10 \\
\hline & At 36 week old & & & \\
\hline & Female & & 1.4 & 5 \\
\hline & Male & & 1.96 & 7 \\
\hline & At 72 week old & & & \\
\hline & Female & 36 & 1.49 & 2.9 \\
\hline & Male & 18 & 2.88 & 5.7 \\
\hline
\end{tabular}




\subsection{Feeding and types of feed used}

Since the demonstration provides full package to the producers, a balanced ration were provided from Deberzeit Agricultural Research Center for the first 16 weeks of age. The producer farmers themselves prepare supplementary feed after 16 weeks from locally available feed sources (wheat,barly,sorgum,maze,salt lime stone based on the training given before the chicken was given. Scavenging was the major means of satisfying their nutrient requirements.

\subsection{Egg production and egg weight}

The egg production performance of the chicken were to be about $41.7 \%$ and $43.6 \%$ at $50 \%$ ( 32 week) egg production and $69.7 \%$ and 70.4 (52week) at the end of data collection period in Digelu-Tijo and Tiyo districts respectively. The result obtained in this study was lower than with the findings reported by Kasa \& Saba (2016) from Jima zone who described $51.8 \%$ and $79.4 \%$ egg production performance at $45 \%$ egg production and at peak period respectively. The difference could be because of agro ecology and management.

The average egg weight was recorded to be $49.8 \mathrm{~g}$ and $51.7 \mathrm{~g}$ at half and peak production time respectively. Average egg weight obtained in this study is slightly higher to the findings by Kasa (2016),Aman et al(2016)and Gezahegn et al (2016) who describes $41.7 \mathrm{~g}$ at $45 \%$ egg production, $40.2 \mathrm{~g}$ at first egg lay and $42.4 \mathrm{~g}$ respectively. According to Grobbelaar et al (2010), to increase egg production under semi- intensive system, farmers must provide the chickens with sufficient housing, a suitable feed type and sound general management practices regarding feeding, hygiene and temperature control. So, from this study lower egg performance might be resulted from poor or minimum feed supplementation, poor scavenging resources around homestead, inefficient management practices and intense cold weather condition which was not supported by energy feed resources during sexual maturity and egg laying period.

\subsection{Partial budget analysis}

Partial budget analysis result is described in (Table 5 ) below. In the current study, Kulumsa Agricultural Research Center together with Debrezeit Agricultural Research Center provide balanced chicken feed up to eight weeks of age, vaccines against common poultry disease, multi-vitamins and poultry house equipment's like feeder, waterer, and infrared light to encourage and build up capability of economically weak participant farmers. All other costs allocated by participant farmers during the study period were taken into account as cost of the demonstration and sale of cockerels, eggs, unproductive hens and existing chickens till end of the study were taken as gain of the demonstration. Depending on these facts participant farmers expend on average 1222.5 birr in Digelu-Tijo and 1210 birr in Tiyo districts and average profit from the production were 6598.33 in Digelu-Tijo and 6892 birr in Tiyo district. On average 5500.38 birr was gained per participant farmer from sale of egg, cockerels and replacement chickens for further breeding and expansion purpose. The income gained in our research result is higher than Kasa and Saba (2016) report at Jimma Zone which was 2453 Ethiopian birr and 1048.9birr by Aman et al (2016) and lower than Tekalgn et al 2019 who reported a net income 6712.2 ETB.

The producer farmers were benefited from the access to animal protein egg and chicken meat in addition to income gained from sell of egg and live chicken. The unite price of cockerels were 200-250 ETH birr and 200$225 \mathrm{ETB}$ birr for female hens in the study areas because the demand for improved chicken was very high. The change in net income $(\Delta \mathrm{NI})$ was calculated as the difference between the change in total return $(\Delta \mathrm{TR})$ and the change in total variable cost $(\mathrm{TVC}) . \Delta \mathrm{NI}=(\Delta \mathrm{TR}-\mathrm{TVC}), \Delta \mathrm{NI}=121,416-22,409=99007$ birr. 
Table 5.partial budget analysis result

\begin{tabular}{|c|c|c|c|c|c|c|c|c|c|}
\hline \multirow[t]{2}{*}{ Districts } & \multirow[t]{2}{*}{ Participants } & \multicolumn{4}{|c|}{ Variable costs (Eth. Birr) } & \multicolumn{4}{|c|}{ total revenue(Eth .birr) } \\
\hline & & $\begin{array}{l}\text { Feed } \\
\text { cost }\end{array}$ & $\begin{array}{l}\text { Chicken } \\
\text { cost }\end{array}$ & $\begin{array}{l}\text { Medication } \\
\text { cost }\end{array}$ & sum & $\begin{array}{l}\text { Live } \\
\text { chicken } \\
\text { sale }\end{array}$ & $\begin{array}{l}\text { Egg } \\
\text { sale }\end{array}$ & Sum & profit \\
\hline \multirow{9}{*}{$\begin{array}{l}\text { Digelu- } \\
\text { Tijo }\end{array}$} & 1 & 850 & 300 & 160 & 1310 & 1000 & 4500 & 5500 & 4190 \\
\hline & 2 & 900 & 300 & 130 & 1330 & 2500 & 5200 & 7700 & 6370 \\
\hline & 3 & 600 & 300 & 200 & 1100 & 2800 & 5500 & 8300 & 7200 \\
\hline & 4 & 800 & 300 & 150 & 1250 & 2600 & 6000 & 8600 & 7350 \\
\hline & 5 & 750 & 300 & 175 & 1225 & 2000 & 5800 & 7800 & 6575 \\
\hline & 6 & 650 & 300 & 125 & 1075 & 1500 & 6100 & 7600 & 6525 \\
\hline & 7 & 700 & 300 & 250 & 1250 & 3000 & 4800 & 7800 & 6550 \\
\hline & 8 & 550 & 300 & 180 & 1030 & 2200 & 5900 & 8100 & 7070 \\
\hline & 9 & 950 & 300 & 95 & 1345 & 2400 & 6500 & 8900 & 7555 \\
\hline Sub total & & 6750 & 2700 & 1465 & 10915 & 20000 & 50300 & 70300 & 59385 \\
\hline \multirow{9}{*}{ Tiyo } & 1 & 1001 & 300 & 215 & 1516 & 2400 & 6400 & 8800 & 7284 \\
\hline & 2 & 670 & 300 & 175 & 1145 & 2005 & 5600 & 7605 & 6460 \\
\hline & 3 & 870 & 300 & 210 & 1380 & 2400 & 4900 & 7300 & 5920 \\
\hline & 4 & 950 & 300 & 165 & 1415 & 2100 & 5700 & 7800 & 6385 \\
\hline & 5 & 790 & 300 & 199 & 1289 & 2500 & 6020 & 8520 & 7231 \\
\hline & 6 & 650 & 300 & 150 & 1100 & 2800 & 5800 & 8600 & 7500 \\
\hline & 7 & 850 & 300 & 200 & 1350 & 2900 & 6000 & 8900 & 7550 \\
\hline & 8 & 890 & 300 & 189 & 1379 & 2600 & 5800 & 8400 & 7021 \\
\hline & 9 & 500 & 300 & 120 & 920 & 2200 & 5400 & 7600 & 6680 \\
\hline Ttotal & & & & & & & & & 62031 \\
\hline \multicolumn{6}{|c|}{$\begin{array}{l}\text { Total variable cost }=22,409 \\
\text { average profit }\end{array}$} & & 1,416 & \multicolumn{2}{|c|}{$\begin{array}{c}\text { 9007birr } \\
5500.33 \text { birr }\end{array}$} \\
\hline
\end{tabular}

\section{CONCLUSION AND RECOMMENDATION}

Most of the participant farmers were benefited from this demonstration through the sale of egg and live chicken for meat and breeding purpose with better price. Koekoek chicken can better adaptable with better production potentials in the highland agro-ecological environments under farmers' management condition compared with indigenous chicken. Feed cost and poor veterinary service were the major challenges for chicken production in the study areas. According to our observation, koekoek chicken cannot meet its nutritional need by scavenging unless supplemented with sufficient feed. So to obtain the required amount of benefit from koekoek chicken under village production system the farmer must supplement two times per day. Scaling up of the dual purpose chicken through training and awareness creation is important to full fill the improved chicken demand and create job for the youth.

\section{REFERENCES}

Alemu Y, Tadelle D. (1998), The Status of Poultry Research and Development in Ethiopia. In: the Proceedings of the 5th Conference, Ethiopian Society of Animal Production, pp. 40-60.

Aman G,MeleseY, Mesfin M, Addisu J, Mebratu A, Asrat T and Edrias D, (2016), Demonstration and performance evaluation of potchestroom koekoek chicken at Areka area,SNNPR .Global Journal of Science Frontier Research : D Agriculture and Veterinary, 16(2).

Demeke S .(2004), Egg production performance of local and White Leghorn hens under intensive and rural household conditions in Ethiopia. Livestock Research for Rural Development 16 (2).

Desalew T, Harpal S, Ashenafi M, Wondimeneh E, and Tadelle D .(2013), Study on productive performances and egg quality traits of exotic chickens under village production system in East Shewa, Ethiopia. African Journal of Agricultural Research 8(13) : 1123-1128.

Dhuguma R.(2009) ,Understanding the Role of Indigenous Chickens during the Long Walk to food Security in Ethiopia. Livestock Research for Rural Development 21 (8)

Gezahegn T, Ashenafi M and BerhanTamir ,(2016) ,Evaluation of the Egg Production Performance in Bovans Brown and Koekoek Chicken Breeds under Varied Seasons and Feeding Regimes in South Wollo Zone, Ethiopia. Global Veterinaria 17 (4): 318-324. DOI: 10.5829/idosi.gv.2016.17.04.103154

Grobbelaar J A N, Sutherland B and Molalakgotla N M. (2010), Egg production potentials of certain indigenous chicken breeds from south Africa. Animal Genetic Resources/Resources génétiques animales/Recursos genéticos animales, 46 : 25-32 DOI: https://doi.org/10.1017/S2078633610000664.

Kasa B and Saba H.(2016), Demonstration and performance evaluation of potchestroom koekoek chicken at Jima 
zone, south western Ethiopia. Journal of Biology,Agriculture and Healthcare,6(15) .available at www.iiste.org.

Leta S and Endalew B .(2010), Survey on Village Based Chicken Production and Utilization System in Mid Rift Valley of Oromia, Ethiopia. Global Veterinaria 5 (4): 198-203.

MoA (Ministry of Agriculture) (1997), National Ruminant Livestock Development strategy of Ethiopia, Addis Ababa, Ethiopia.

Moges F, Abera M, Tadelle D .(2010a), Assessment of village chicken production system and evaluation of the productive and reproductive performance of local chicken ecotype in Bure district, North West Ethiopia. African Journal of Agricultural Research 5(13): 1739-1748.Available online at http://www.academicjournals.org/AJAR.

Samson L, Endalew B, Tesfa G .( 2013), Production Performance of Fayoumi Chicken Breed Under Backyard Management Condition in Mid Rift Valley of Ethiopia. Herald Journal of Agriculture and Food Science Research 2(1):078-081.Available online at http://www.heraldjournals.org/hjafsr/archive.htm.

Tadelle D and Ogle B.( 2001), Village poultry production system in the central high lands of Ethiopia. Tropical Animal health and production, 33:521-537.

Tadelle D, Million T, Alemu Y, Peters K J .(2003b), Village chicken production systems in Ethiopia: Use patterns and performance valuation and chicken products and socio-economic functions of chicken. Livestock Research for Rural Development (15) 1.

Tekalegn Y, Etalem T, Alemayehu A and Misba A., (2019) On-Farm Evaluation and Demonstration of Dual Purpose Chicken "Potchefstroom koekoek" Technology Packages in Sidama Zone, Ethiopia. World Journal of Agricultural Sciences 15 (5): 317-323.

Wilson R T .(2010), Poultry production and performance in the Federal Democratic Republic of Ethiopia. World's Poultry Science Journal, 66(3):441-454.DOI: https://doi.org/10.1017/S0043933910000528. 